\title{
Construcción y aproximación musical a las identidades frágiles en la película dramática Todo sobre mi madre
}

\author{
Construction and Musical Approximation of Fragile Identities in the \\ Drama Film All about My Mother
}

\author{
Rastko Buljančević \\ Academia de las Artes de Novi Sad \\ rastko.buljancevic@gmail.com \\ ORCID iD: https://orcid.org/0000-0001-6247-8163
}

\section{RESUMEN}

Probablemente uno de los temas de debate más controvertidos en la historia de la psicología, filosofía, antropología cultural y sociología está relacionado con el significado del concepto de la identidad. Además de las obras literarias, donde la palabra escrita tiene un papel crucial en la decodificación de los personajes (especialmente sus emociones y otros aspectos psicológicos), el arte cinematográfico nos deja espacio para profundizar aún más en el fenómeno de la identidad, gracias a los potenciales expresivos o evocadores de los medios audiovisuales. Pedro Almodóvar, uno de los autores contemporáneos más populares y reconocidos en el mundo del cine, en sus 22 largometrajes (hasta el momento), ha incorporado varios conceptos de identidad, intentando crearlos, reconstruirlos, modificarlos y darles una nueva forma a través de los diversos elementos fílmicos. Este artículo está enfocado en la reconstrucción de la identidad personal con la música y la imagen cinemática en el "almodrama" Todo sobre mi madre (1999). Se defiende la hipótesis de que la música en el cine es capaz de representar y reconstruir el self de un personaje con la identidad frágil y extraviada, un tipo de identidad que encontramos con frecuencia en el universo almodovariano.

Palabras clave: Pedro Almodóvar, Todo sobre mi madre, identidad personal, música de cine, self/sí mismo. 


\title{
RASTKO BULJANČEVIĆ
}

\begin{abstract}
One of the most controversial debate topics throughout the history of philosophy, psychology, cultural anthropology, and sociology has to do with the concept of identity. In addition to literary works, where the written word plays a crucial role in decoding characters (especially their emotions and other psychological aspects), the art of cinema gives us the space to fathom even more the phenomenon of identity by means of the expressive and evocative potentials of audiovisual media. Pedro Almodóvar, one of the most esteemed contemporary directors in the world of cinema, has incorporated several concepts of identity in his 22 feature films (so far), trying to create, reconstruct and modify them, and to give them a new shape through the different components of the film. This article aims at presenting the reconstruction of personal identity through the music and the cinematic image in the "Almodrama" All about My Mother (1999). It is intended to defend the hypothesis that film music is capable of rebuilding and representing the self of a character with fragile and misplaced identity, a type of identity that can be frequently found in the Almodovarian universe.
\end{abstract}

Key Words: Pedro Almodóvar, All about my Mother, personal identity, film music, self.

Buljančević, R. (2022). Construcción y aproximación musical a las identidades frágiles en la película dramática Todo sobre mi madre. Cuadernos de Investigación Musical, (14), pp. 267-295.

\section{INTRODUCCIÓN}

La identidad, generalmente, podríamos definirla como un principio de cohesión asimilada por un sujeto o un grupo, que se construye y modifica a través del ambiente y sus significantes. La identidad personal, como el conjunto de rasgos y circunstancias que nos definen como personas, no tiene que ser algo de lo que somos siempre conscientes o que tenga que ver con nuestra voluntad. Cabe mencionar que lo personal frecuentemente entra en el ámbito del inconsciente -el dominio irreconocible o más profundo de la mente del sujeto $^{1}$. No obstante, como lo confirmó el filósofo David Lewis (1986), todo es idéntico a sí mismo y nada es idéntico a cualquier otra cosa, es decir, dos cosas nunca podrían ser completamente iguales (pp. 192-193). En consecuencia, lo que caracteriza a los personajes de las películas de Almodóvar es que cada (anti)héroe suyo tiene una presentación original; en otros términos, se indica un formato explícito en la correspondencia entre su self (una estructura interna de la mente que representa el núcleo de la identidad personal $)^{2}$, los “otros" y el ambiente fílmico ${ }^{3}$. Incluso, en casos particulares es posible notar los síntomas de despersonalización, especialmente cuando individuos en la película dejan de ser conscientes

\footnotetext{
${ }^{1}$ Esta interpretación del "inconsciente" es más cercana a la noción freudiana que a la lacaniana, sin reducirse por completo a lo reprimido o traumático.

${ }^{2}$ Según la breve explicación de Kohut, el self representa el contenido del aparato mental (Kohut, 1996a, p. 389).

${ }^{3}$ Con el ambiente fílmico se entiende el entorno en el que operan los personajes.
} 
de su entorno. Por lo tanto, es importante analizar los personajes almodovarianos con profundidad y observar sus construcciones y modificaciones identitarias.

En el cine de Pedro Almodóvar podemos observar varios tipos de personajes emocionalmente inestables con desgarrados, traumatizados y reprimidos fragmentos de su identidad. En realidad, se trata de personas estereotipadas, oprimidas y marginadas que no encajan en los flujos convencionales/normativos de la sociedad. Los personajes almodovarianos se encuentran en una búsqueda constante y extensiva de su identidad o como probablemente diría Jaques Lacan, en persecución del objeto primordialmente perdido e inaccesible ${ }^{4}$. Según la opinión de la psiquiatra serbia Katarina Petrović, Almodóvar estableció un prototipo de héroe que, en la cultura europea de los años 90, manifestó los traumas de la inclusión en la estructura incoherente del mundo moderno, un prototipo que implicó los comportamientos impredecibles, extremos y clínicamente notorios (2016, p. 4) 5 . Por lo tanto, a través del discurso psicoanalítico bien adaptado, sería posible vincular los sujetos fílmicos con el contenido audiovisual y el modo en que los oyentes lo perciben y analizan en diferentes niveles de su sensorialidad y cognición ${ }^{6}$.

Diversas teorías psicoanalíticas, cuyo contenido inicialmente revela el mundo inconsciente y sus símbolos indefinidos, abstractos, reprimidos y escondidos, se pueden utilizar como un modelo discursivo primario para analizar el comportamiento humano, sus conflictos internos, sus deseos reprimidos o incluso inalcanzables. Gracias al trabajo del psicoanalista estadounidense de origen austriaco Heinz Kohut, que durante los años 60 estableció una nueva dirección del psicoanálisis llamada psicología de self o psicología del sí mismo ${ }^{7}$, es posible desarrollar aún más el tema de la progresión y la reconstrucción de la identidad personal, que coexiste más allá de los instintos básicos freudianos, como, por ejemplo, el dualismo pulsional (pulsiones de vida y muerte) o totalización de los impulsos sexuales. Así, por ejemplo, el psicoanálisis empezó a observar cómo se fortalece o rompe la experiencia de un self, que en el sentido psicoanalítico es variable y de ninguna manera coextensivo con los límites de la personalidad (Kohut, 1966, p. 244). Por lo tanto, se podría decir que, en ciertos estados psicológicos, el "yo" puede expandirse mucho más allá de los límites (aparentemente notables) del ego o incluso del individuo per se. Kohut, por ejemplo, propuso diferentes métodos psicoanalíticos, claramente diferentes a los de Freud o Lacan, insistiendo en el concepto de la empatía, es decir, en la relación/compresión empática entre el psicólogo y el

\footnotetext{
${ }^{4}$ El objeto perdido es el objeto pequeño "a”, que forma una parte importante del psicoanálisis lacaniano. Sin embargo, ese concepto no va a ser abordado en este trabajo (para mayor información, ver Lacan, 1998).

${ }^{5}$ Katarina Petrović (2016), refiriéndose al área de la psicología clínica y la psiquiatría, está considerando que en los personajes de Almodóvar se encuentran las características propias del trastorno límite de la personalidad (p. 3).

${ }^{6}$ Según la opinión de Nicola Dibben (2002), extraída del discurso sobre la música y el género, la música puede alentar a los oyentes a adoptar una posición de sujeto particular (p. 129) que igualmente podría ser extensible a la banda sonora. Por eso se propone la expansión del espacio perceptivo y comunicativo de la escucha activa cinematográfica y abandonan los planteamientos teóricos, como los de Kurt London o Claudia Gorbman, que niegan esa posibilidad (veáse, por ejemplo, Chion, 1993; Smith, 1996; Sergi, 2001; Grainge, 2008; Cenciarelli, 2021).

${ }^{7}$ Hay que mencionar que los modelos teóricos de la psicología del sí mismo son básicamente opuestos al psicoanálisis lacaniano. Sin embargo, el objetivo de este artículo no es reexaminar o cuestionar ciertos conceptos psicoanalíticos.
} 


\section{RASTKO BULJANČEVIĆ}

paciente. Esa aproximación menos distanciada facilita la apertura del paciente, y concretamente en el caso de los personajes almodovarianos, los coloca fuera de los márgenes sociales y culturales donde, generalmente, han hecho aparición sus alteridades suprimidas y juzgadas a priori. Analizando diferentes tipos de personajes en la filmografía de Almodóvar, es posible distinguir varios altibajos progresivos que significativamente afectan la estructura y dinámica de su personalidad, cuando el componente musical describe, modifica o simbólicamente reconstruye el nuevo yo o el yo modificado de los sujetos fílmicos. Precisamente la banda sonora posee el poder de denotar y simbolizar las identidades múltiples de los personajes almodovarianos, construyendo o simplemente demostrando sus relaciones interpersonales con otros self-objetos a través del contenido sonoro ${ }^{8}$.

El objetivo de ese trabajo es demostrar cómo se revive, modifica y transmite la imagen de un self en el mundo del cine a través del sonido, es decir, cómo la audiencia lo ve, lo percibe, lo analiza y, por último, relaciona los actores con el elemento musical polivalente que está causando diferentes tipos de identificaciones ${ }^{9}$. A diferencia de la observación de Theodor W. Adorno ${ }^{10}$, la música, el lenguaje y la imagen cinemática frecuentemente interactúan y en la mayoría de los casos son inseparables del resto de los elementos audiovisuales. De acuerdo con José Nieto (1996), la simbiosis de música e imagen no refleja solamente "un hecho natural", sino "uno de los medios de expresión más ricos" (p. 28), o, en otros términos, una coherencia, estructura y dramatúrgica irreemplazable que forman una parte crucial en la representación musical de las integraciones identitarias. Sin embargo, es importante mencionar que la música misma puede simbolizar, representar y expresar sucintamente sus elementos sensoriales, emocionales y cognitivos durante la proyección fílmica. Por lo tanto, en el tejido audiovisual se inscriben diferentes niveles de narración, significación y focalización musical, que permiten a la música conservar distintos grados de autonomía. Todo este proceso se deriva de la siguiente hipótesis: la música (la música en general) es un arte referencial, independientemente de su contenido programático, ideológico, estructural o textual. A pesar de que la referencialidad de la música, especialmente la música instrumental, ha sido el tema de los grandes debates durante los siglos XIX y XX, hoy, en una era de posteoría, de posverdad y de una realidad invertida, aumentada o hiperreal, es imposible negar que la música, a pesar de ser una de las artes más abstractas, inscribe en sí misma ciertos conocimientos y verdades que la convierten, o por lo menos la acercan, a un arte representativo. Como ha escrito la musicóloga española Herminia Arredondo Pérez (2014), una canción puede abrir "múltiples significados y formas de construir la identidad

\footnotetext{
${ }^{8}$ Self-objeto u objeto del self es un término de Heinz Kohut, crucial en su teoría psicoanalítica. Las experiencias de los self-objetos, que se constituyen por mediación de las relaciones interpersonales entre el sí mismo y los otros, son esenciales para el desarrollo coherente y completo de un "yo". Eso otra vez indica la diferencia entre la psicología de self y la teoría psicoanalítica freudiana, donde el desenvolvimiento del sujeto exclusivamente se observaba analizando y observando su parte inconsciente, es decir, sus impulsos sexuales reprimidos (para mayor información sobre el concepto de self, ver Kohut, 1971).

9 Según la musicóloga y teórica de cine, Anahid Kassabian, las partituras fílmicas y las bandas sonoras condicionan dos procesos de identificación específicos: identificaciones asimiladas (assimilating identifications) e identificaciones afiliadas (affiliating identifications) (ver Kassabian, 2001). No obstante, en este trabajo no se van a utilizar dichos conceptos. Más bien, por identificaciones se alude a la conexión asociativa que el contenido musical establece con el espectador/oyente fílmico.

${ }^{10}$ De acuerdo con la opinión de Adorno y Eisler (1976), las divergencias fundamentales entre palabra e imagen son registradas a través de la inconsciencia del espectador (p. 99).
} 
personal y colectiva para los oyentes, connotaciones que incluso exceden los orígenes de su creación" (p. 143) ${ }^{11}$, lo que confirma una vez más el potencial significativo del contenido musical. De cualquier modo, no solamente el apoyo textual hace que la música sea representativa, sino otros componentes como una programática latente en el guion, la habilidad mimética de la música ${ }^{12}$, su contenido semántico o el poder narrativo, poético y expresivo del sonido mismo.

Una de las funciones más importantes de la música en la filmografía de Pedro Almodóvar es atraer oyentes y causar ciertos efectos en cada miembro de la audiencia. Por ello, es importante mencionar la intención del director de dejar una impresión muy profunda en los espectadores, con el objetivo de reexaminar sus metas, valores morales e ideales, y despertar en ellos los sentimientos y afectos de emotividad, comprensión y empatía hacia aquellos que en la vida real son condenados por diferentes instituciones del poder o la sociedad (Buljančević, 2020, p. 79). Eso no es posible conseguirlo completamente con los medios visuales, o con las obras de arte estáticas que carecen de temporalidad o del efecto de dinamismo que produce un objeto en movimiento. Por tanto, a las películas de Almodóvar no se aplica la famosa, pero hoy argüible idea de Glaudia Gorbman de que la música es mejor en el cine cuando es "inaudible" (ver Gorbman, 1987) ${ }^{13}$. Para entender el comportamiento de los protagonistas, junto con todas sus pasiones, ideologías, remordimientos, nostalgias y tendencias, es necesario percibir y analizar cómo se incorpora el contenido musical en el tejido de la película, acompañando sensorialmente la transformación de los personajes principales, la cual, entre otras cosas, nos permite considerar cómo se percibe, desarrolla, sostiene o repara un self mal construido. Observando la reflexión de Kathleen Vernon (2005) que dice "las canciones de las películas de Almodóvar son vasos comunicantes entre el director y la audiencia” (p. 378), se puede inferir que el componente musical es crucial para el proceso de la interpelación a los oyentes fílmicos y una comprensión integral de la realidad cinematográfica. Es más, la música simbólicamente puede anticipar la acción o el

\footnotetext{
${ }^{11}$ No obstante, conviene aclarar que la autora estaba escribiendo sobre un género musical concreto - la copla. ${ }^{12}$ Es importante destacar la capacidad de la música de imitar la realidad cinematográfica, pero solamente de una manera ingenua, simbólica o figurativa. La música no puede literalmente mimetizar una realidad como algunas interpretaciones de "lo mimético" lo insinúan. Wladyslaw Tatarkiewicz indicó que el concepto de mimesis (palabra de origen posthomérico), se cambió significativamente a lo largo de la historia. Según el historicista y filósofo polaco, en la época antigua (antes del siglo V a. de J. C), "la imitación no significaba reproducir la realidad externa, sino expresar la interior” (Tatarkiewicz, 2001, p. 301). Esta posición teórica sería más apropiada para la comprensión del poder mimético de la música fílmica, que no reproduce el mundo externo, sino, más bien, la interioridad (no completamente expuesta en la capa visual de la película) de los personajes, sus identidades, ideologías y el medio ambiente.

13 Jeff Smith criticó fuertemente la idea gorbmaniana de la inaudibilidad de la música cinematográfica, especialmente su aplicación de la teoría psicoanalítica (ver Smith, 1996). Es más, el concepto de la inaudibilidad de la música de cine también fue cuestionado por varios compositores como Max Steiner. Miklós Rózsa incluso llamó a ese concepto una teoría tonta (Thomas, 1991, p. 27). Aunque Alberto Iglesias nutre una relación complementaria entre los matices visuales y auditivos de la película, el poder perceptivo de la banda sonora es imposible de reducir a un "rellenador de huecos", incluso cuando parece que el contenido musical principalmente profundiza la expresión de la imagen cinematográfica.
} 


\section{RASTKO BULJANČEVIĆ}

comportamiento de los personajes, lo que es explícitamente notable en la película Todo sobre mi madre $(1999)^{14}$.

Se trata de una obra artística llena de personajes traumatizados, con identidades e ideologías diversas, problemáticas y complejas ${ }^{15}$. Reconstruyendo sus pasados junto con una parte de su personalidad, ellos tratan de reencontrar su propia esencia. La importancia de la música y su conexión con la narrativa visual se confirma por el hecho de que la banda sonora está presente a partir del comienzo mismo de la película. Además, casi todos los protagonistas se pueden relacionar con un contenido musical, sin el cual sería difícil entender en profundidad la constelación de sus identidades frágiles y oscurecidas. Parece que la banda sonora está circulando alrededor de la trayectoria de Manuela (Cecilia Roth), la protagonista principal, y unos fragmentos identitarios constitutivos de Esteban (Eloy Azorín), la actriz lesbiana Huma Rojo (Marisa Paredes) y la Hermana Rosa (Penélope Cruz). Sin embargo, en el disco Todo Sobre Mi Madre ${ }^{16}$, se encuentra el tema musical Pavana para Agrado, derivado del lenguaje musical de Erik Satie ${ }^{17}$, que no fue incluido en el corte fílmico final. En realidad, el contenido sonoro, que podría profundizar la fragilidad y fluidez identitaria del personaje secundario de Agrado (Antonia San Juan), queda fuera del marco cinematográfico, a pesar de tener una poética, sensorialidad e instrumentación notables. Finalmente, veamos cómo la música describe, define, fusiona o separa las identidades fragmentadas y desgarradas de los personajes.

\section{REPRESENTACIÓN SONORA DE LA NARRACIÓN FÍLMICA: MÚSICA, IDENTIDADES Y LOS PERSONAJES PRINCIPALES EN LA PELÍCULA TODO SOBRE MI MADRE}

La música de cine constituye y revitaliza su potencial dramático, emocional, sensorial, cognitivo, estético, económico, ideológico, político e identitario a través de sus mecanismos de poder $^{18}$, liberándolos o intencionalmente escondiéndolos de los oyentes fílmicos. Junto

14 Por ejemplo, se podría argumentar que el sonido instrumental del tango argentino potencialmente anticipó la muerte de la Hermana Rosa, antes de lo que el espectador hubiese podido deducirlo a través de un recurso visual o lingüístico.

15 En la película Todo sobre mi madre, como lo apunta Joseba Gabilondo (2005), hay un doble proceso de formación identitaria: "uno que es global, maternal y migrante, y otro que es de duelo e introyectivo" (p. 304). No obstante, en este trabajo primariamente va a ser discutida la importancia del componente sonoro para la formación de la identidad personal y otros tipos de identidades que lo influyen.

16 Alberto Iglesias compuso la banda sonora original de la película, que consiste en 18 temas musicales, incluyendo tres temas preexistentes.

17 La referencia intertextual a la primera Gnossienne de Satie es explicitamente notable. Además, ambas composiciones, a pesar de la diferente instrumentación y estilo, comparten un carácter melancólico.

${ }^{18}$ Los mecanismos de poder "se dirigen al cuerpo", como dijo Foucault (1993, p. 178), pero primariamente su pensamiento sobre esos mecanismos se dirigió al sexo, la sexualidad y la reproducción. La música también puede regular y generar cierto poder institucional (especialmente político), geográfico, cultural, religioso, histórico, social o personal. Es por ello que los mecanismos de poder de la música se manifiestan en diferentes esferas de acción, cuando las estructuras musicales en cierta forma interfieren los otros canales de comunicación, modificándolos ligera o copiosamente. Precisamente por mediación de la ideología, de la cual, según Louis Althusser no hay salida (ver Althusser, 2003), la música se convierte en "portadora" de poder sobre alguien o algo. El poder que coexiste en su propio medio sonoro viaja al oído del oyente, alcanzándolo a través de su afección, sensorialidad y cognición. La música de cine tiene un poder similar para producir e inscribir ciertos conocimientos conceptuales y procedimentales, especialmente los invisibles, indiferenciados o ambivalentes, y muchas veces intertextuales, escondidos dentro del propio tejido sonoro en lugar de un referente visual. Por lo tanto, el poder (musical), como lo diría Foucault, está indisolublemente ligado al 
con todos los componentes de la narrativa fílmica, el elemento sonoro-visual es una parte crucial de la creación y representación de los personajes y sus identidades, tanto individuales como colectivas. La banda sonora original y los temas preexistentes de la película Todo sobre mi madre construyen un clima ambiental muy diverso, transfiriendo varias imágenes, metáforas, símbolos y connotaciones potenciales de las referencias psicológicas. Lo supuestamente "indecible" o "inefable" de la música establece y transmite varios conocimientos e información sobre los personajes, sus relaciones interpersonales con otros individuos y colectivos, la dinámica de la escena y hechos que aparentemente no son completamente visibles o claramente presentes en la capa visual de la película.

Manuela es una enfermera de origen argentino y madre soltera que vive con su hijo adolescente Esteban. Todo lo que Esteban logra saber sobre su padre es que murió antes de que naciera. En consecuencia, durante toda su vida le falta una figura paterna con la cual, a través del self-objeto saludable, poder identificarse. Como regalo de cumpleaños, Esteban pide a su madre que le cuente la historia sobre su padre, lo que Manuela le promete hacer después de ver la obra de teatro Un tranvía llamado deseo, protagonizada por su actriz favorita, Huma Rojo. Justamente después de la actuación, mientras están parados bajo la lluvia, Esteban intenta obtener un autógrafo de la actriz, y muere trágicamente en un accidente de tráfico. Desde el fallecimiento repentino del joven, el mundo de Manuela se derrumba completamente: ella se encuentra bajo un estado de shock emocional. En dicha escena fílmica, se pierde el protagonismo absoluto de la música, cuando en su tejido espaciotemporal, la narrativa audiovisual recibe el sonido conspicuo anempático de la lluvia, el ruido diegético de los frenos del coche (sonido involuntario), o un grito impactante y repentino de Manuela que, en este caso, simboliza la dramatización trágica de una interrupción no anticipada de la vida.

Debido al desenlace trágico y a su limitada aparición durante las primeras secuencias fílmicas, Esteban no tuvo oportunidad de desarrollar en su personalidad los aspectos importantes de la madurez psicológica, o sea, la integración completa de su self, a pesar de haber establecido contacto empático con su madre. En su vocación como escritor, descubrió y formó gran parte de su identidad. En realidad, gracias a su cuaderno podemos contemplar algunos de sus objetivos y deseos más profundos. Uno de ellos sería el deseo de conocer toda la verdad sobre su padre, o por lo menos, saber quién es/era. Por haber sido privado de una experiencia muy significativa de establecer la relación interhumana con el self-objeto de su padre, queda cuestionable si el completo desarrollo de la personalidad de Esteban podría haber ocurrido sin una figura paterna. A pesar del hecho de que su madre hizo todo lo que estaba en su poder para compensarle por esa pérdida, no ha podido reemplazar la ausencia de un padre. En algunas páginas de su diario, que según Marsha Kinder (2005) representa un "vehículo narrativo" (p. 263), Esteban escribe lo siguiente:

ESTEBAN (la voz en off): Anoche mamá me enseñó una foto. Le faltaba la mitad. No quise decírselo, pero a mi vida le falta también un trozo [...]. Esta mañana he revuelto

conocimiento. Incorporando el mismo pensamiento foucaultiano: el poder y el conocimiento están muy arraigados en lo que los constituye (Foucault, 1980, p. 87). 


\section{RASTKO BULJANČEVIĆ}

en sus cajones y he descubierto un fajo de fotos. A todas les faltaba la mitad. Mi padre, supongo. Quiero conocerle. Tengo que hacerle comprender a mamá que no me importa quién sea, ni cómo sea, ni cómo se portó con ella. No puede quitarme ese derecho (Almodóvar, 1999, p. 192).

Teniendo en cuenta la narrativa transmedia del cine, es decir, la coexistencia de diferentes medios de comunicación dentro de un relato cinematográfico, se puede argumentar que la música instrumental reconoce, refleja y profundiza los afectos y emociones de Esteban que potencialmente provienen de su pensamiento escuchado a través de su voz en off. Pero, la relevancia semántica de la música incidental no deriva solamente del potencial afectivo del sonido mismo, sino de la capacidad conceptual de transmitir varios conocimientos sobre Esteban, especialmente ese conocimiento que no proviene del mundo diegético o de la capa visual de la película. Eso confirma el fragmento de la banda sonora Le faltaba la mitad [11:4312:08 $]^{19}$, que consiste en tres secciones melódicas y una instrumentación diversa y heterogénea. El sonido constituyente de las cuerdas con una estructura estable representa el fondo musical de la escena, apoyando la discontinuidad tanto melódica como rítmica que está intensificada por el sonido del piano ${ }^{20}$. Además, los instrumentos de cuerda están en conflicto con la parte de piano, mientras el sonido de percusión es como si tuviera una función enunciativa de un contenido indecible que, a través de la capacidad semántica/significativa y connotativa de la música, es posible analizar o simbolizar. El contenido musical en este caso no pertenece al ser de Esteban, simplemente informa sobre él, o, mejor dicho: está reflejando sus recuerdos a través de la voz de otros personajes en el relato cinematográfico. Por lo tanto, la narración, temporalidad, espacialidad, y focalización musical están aplicadas en un nivel narrativo secundario, aunque no por ello son musicalmente o dramatúrgicamente menos expresivas.

El tema preexistente Gorrión [8:31-11:14] acompaña a Esteban en los últimos momentos de su vida, mientras está en la cafetería escribiendo notas en su diario o viendo el espectáculo Un tranvía llamado deseo con su madre. Se destaca un sonido reconocible del acordeón que está simbólicamente anunciando un desarrollo trágico de su personaje, es decir, la anulación completa de su self. Por tanto, el sonido del acordeón sacude las distintas reacciones sonoras, anunciando la inevitable tragedia humana.

\footnotetext{
${ }^{19}$ Los tramos de metrajes identificados en este trabajo coinciden con los puntos de metrajes del DVD hechos por el estudio Filmax y el material presente en la plataforma Netflix.

${ }^{20} \mathrm{La}$ aparición de discontinuidad en la música usualmente ocurre por la interrupción del flujo sonoro continuo. Los cambios pueden ser notables en la fluctuación tanto rítmico-métrica como melódica, armónica, dinámica o agógica. La discontinuidad también implica la desintegración estructural a un nivel macro o micro de la forma musical, que en algún modo está interfiriendo con la coherencia espacio-temporal de la música o contenido audiovisual en el cine. No obstante, la discontinuidad musical no tiene que provenir solamente de los componentes musicales, sino también puede operar a través del nivel histórico, genealógico, ideológico o político del discurso, liberando su capacidad conceptual-narrativa que no obedece a las normas de un canon dominante: el canon que simbolicamente podemos llamar el "artífice" de la continuidad.
} 


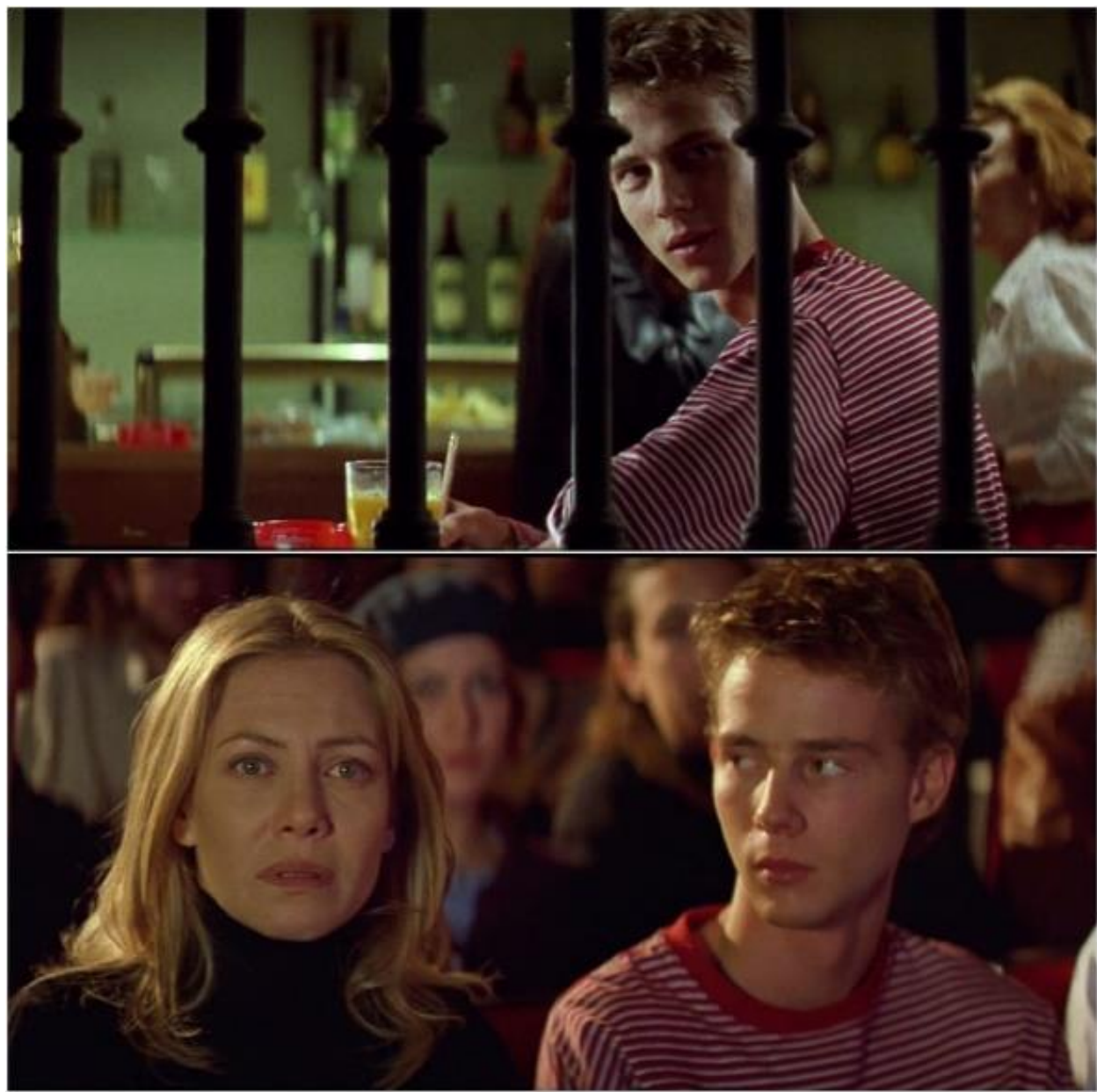

Fig. 1: El sonido fatídico del acordeón acompañando a Esteban en la cafetería y en espectáculo con su madre.

(C) EL DESEO, D.A., S.L.U.

El contenido musical también revela un aspecto importante de la identidad personal de Esteban, crucial para la comprensión coherente de su comportamiento, de sus objetos de deseo o de su interacción con el entorno. Esto particularmente demuestran las partituras musicales Esteban mi bijo [05:21-05:45] y Tras el corazón de mi bijo ([17:51-19:57], [1:06:581:07:23] y [1:29:21-1:31:04]). El tema Esteban mi hijo consiste en la sucesión de los sonidos del vibráfono, la trompeta y las cuerdas que aumentan y denotan la intensidad tanto dinámica como poética y expresiva de la escena, mientras la partitura Tras el corazón de mi hijo representa diferentes etapas de la sublimación de una identidad masculina, es decir, la reconstrucción y re-asimilación post mortem de una identidad adolescente. Es más, el sonido de la trompeta, como una materialización sonora de un selfindiferenciado, está directamente intensificando la dramaturgia audiovisual con la apariencia de la foto de Esteban, mostrada por parte de Manuela a Lola (Toni Cantó), su ex marido. Incluso se podría argumentar que el sonido de la trompeta es, en realidad, el sonido especificador de Esteban -su significante sonoro ${ }^{21} \mathrm{o}$ su

${ }^{21}$ Según Christian Metz, el significante de la música también es perceptivo, "pero menos 'extendido' que el de cine” (Metz, 2001, p. 57). Esto plantea la cuestión de cuán fuerte es realmente el significante musical constituido 


\section{RASTKO BULJANČEVIĆ}

imagen acústica ${ }^{22}$. Por eso el dicho sonido representa una fracción concluyente de la esencia de Esteban, a pesar de que el contenido musical de la película no construye directamente su identidad porque para él, la palabra escrita era más importante que la música. Esa utilización de la música saca a la superficie el poder sonoro para reconstruir y trasladar una esencia identitaria de Esteban, es decir, el fragmento integrante de su self que no podría haberse desarrollado por completo. Gracias a la banda sonora tanto musical como no musical, Almodóvar logró revivir su personaje, aunque póstumamente, a través del contenido audiovisual que rescata fragmentos de las relaciones interpersonales entre sí mismo y el selfobjeto crucial: su madre.

Por otro lado, las peleas y las turbulencias internas de la protagonista principal, de una forma diegética o extradiegética de la narración, en la mayoría de sus ocurrencias tienen una representación musical. En la secuencia introductoria de la película se entreoye un sustentáculo musical, una pieza de la banda sonora con el título Soy Manuela [00:21-02:56]. Incluso en el primer minuto de la película, cuando todavía faltan acontecimientos centrales de la acción, podríamos obtener una reflexión sobre la identidad personal de Manuela -cuya cara todavía no presentimos, pero parcialmente anticipamos los rastros de sensibilidad o fragilidad primariamente escondida. La primera secuencia de la película nos introduce a un entorno hospitalario con la imagen de un suero fisiológico. Combinando diferentes técnicas para el montaje de imágenes con sonido, Almodóvar destaca la discontinuidad sonora frente a la continuidad visual ${ }^{23}$, integrándolos en una totalidad coherente. Un enfoque acentuado hacia la primera y quinta nota del motivo que potencialmente interrumpen la unidad cohesiva del conjunto musical o, por el contrario, saca a la superficie lo inconsciente de la música que adquiere una función denotativa o pronominal, ocultamente metaforizando "lo imposible" de decir. El motivo de piano, que puede ser considerado como un sonido introductorio de la identidad de Manuela, ${ }^{24}$ con una frase prolongada y melodía recargada ${ }^{25}$ está simultáneamente acompañado del sonido de un monitor del ritmo cardíaco, cuando por

por el sonido extradiegético. Sin embargo, como lo observa José Ángel García Landa (1998), "no todos los 'significantes' del personaje han de pertenecer forzosamente a la acción”, es decir, al múndo diegético (p. 83). Por lo tanto, no hay que negar el poder de la música incidental de convertirse en un significante sonoro o incluso de formar una cadena de significantes. Aún así, en el caso de la música instrumental, las posibilidades significantes pertenecen a las categorías perceptuales más abstractas, que a veces requieren el oído agudo de un músico o musicólogo entrenado que pueda reconocerlas e interpretarlas acertadamente.

${ }^{22}$ La imagen acústica (entendida como una entidad mental) para Saussure no es "el sonido material" o "cosa puramente física" sino "su huella psíquica, la representación que de él nos da el testimonio de nuestros sentidos" (1978, p. 128). Aunque el propio significante (según la terminologia de Saussure) no tiene materialidad, el fragmento extradiegético no pierde su materialidad que construyó gracias a su conexión o combinación con otros significantes dentro del medio cinematográfico.

${ }^{23}$ En la partitura Soy Manuela, la discontinuidad sonora se entiende a través de los tres aspectos dramatúrgicos:

1. la desincronización entre el contenido sonoro musical y no musical

2. el cambio repentino de la fluctuación rítmico-métrica del sonido pianístico

3. los recursos expresivos de la acentuación que no acompaña una sucesión métrica de micropulsaciones regulares dentro de una frase musical.

24 Otro instrumento que hipoteticamente podria relacionarse con un fragmento identitario de Manuela sería la armónica, pero solamente de un modo parcial o transitorio.

${ }^{25}$ Como lo indica Rebeca Iglesias Prieto (2015), la película mayormente capta las melodías anacrúsicas (p. 104), incluyendo el primer bloque musical. La densidad del tema musical Soy Manuela, repartida entre varios instrumentos, proviene del ritmo agitado de un tiempo levemente moderado, lo que simbolicamente, todavía de una manera abstracta, imputa a una fragmentación identitaria. 
primera vez se presenta el personaje de Manuela en su lugar de trabajo. El tema introductorio, que según Guilherme Maia se parece a la música de tango de Astor Piazzola (Maia, 2010, p. 21), está prácticamente creando una interiorización subjetiva del personaje, insinuando a los espectadores su estado emocional: mostrándolo absorto en sus sentimientos, anhelos, emociones y recuerdos turbulentos que aún no ha realizado o experimentado en la acción. El motivo de las cuerdas de tres notas consiste en un movimiento cromático descendente que, a través del gesto musical del suspiro, denota la eficiencia perceptual de la expresión de sufrimiento, y, por lo tanto, también simboliza una abstracción musical de una identidad frágil. Debido a la falta de componente textual, se podría decir que la primera secuencia fílmica no habría logrado una progresión dramatúrgica adecuada sin un contenido musical, anunciándonos elementos de una tragedia potencial o simplemente una tristeza profunda que la audiencia puede contemplar, pero que en esa etapa fílmica no puede entender. Por lo tanto, el contenido sonoro inicial, a través de su interacción con el tejido visual de la película y sonidos inscritos en la diégesis, nos revela una parte identitaria de Manuela: su identidad laboral.

Mientras en una sala Manuela está firmando el permiso para la donación de órganos, se escucha el tema original La mecánica del trasplante $[15: 20-17: 27]^{26}$. La narración audiovisual se transmite continuamente. Sin embargo, a través del procedimiento musical se favorece la discrepancia sonora entre el contenido musical y los sonidos no musicales que captan el entorno hospitalario. El dialogo alterno entre las cuerdas y el clarinete, y después la flauta, está estructuralmente interpuesto con un pasaje del piano convirtiéndolo en un núcleo musical no coherente, que está reflejando la división interna: el estado afectivo y la ansiedad de una madre desconsolada, presionada para tomar una decisión repentina en una situación en la que aún no ha asimilado la pérdida de su hijo. Esta experiencia de la lucha interior tiene una representación musical muy dramática, mostrada a través de repentinas oscilaciones tanto rítmicas como métricas (la marcha progresiva de tresillos) que profundizan aún más en la intensidad, transmitida por una expresión lírica. Rastros de una identidad deshecha, o más bien, la destrucción o desintegración del propio self de la protagonista, están expuestos en los motivos musicales fragmentados. Cada motivo de esa banda sonora participa en la reconstrucción, modificación o simplemente descripción del self de Manuela, que es incapaz de integrarse de nuevo (en un modo completo) en su personalidad. Por otro lado, el contenido musical de ese tema posee una coherencia sonora, con tres diferentes funciones significativas: descriptiva, narrativa y ambiental, con la capacidad mimética de la música para expresar lo interior de la realidad fílmica, o, mejor dicho, la verdad interior de Manuela y la narrativa visual de la escena. El tema musical se convierte en un referente narrativo no solamente porque está reforzando el suspenso de la escena, sino la música misma, como lo diría Kathryn Kalinak (1992), es parte del proceso que la crea (p. 31). Debido a que la escena está privada del acto comunicativo lingüístico, y por ello de la función referencial o denotativa del lenguaje, el recurso melódico, a pesar de la abstracción, asume el papel de significante conceptual que denota la fragmentación identitaria de Manuela. Por eso el componente ${ }^{26}$ El bloque musical La mecánica del trasplante aparece por primera vez durante un simulacro médico de Manuela,
como una autorreferencia a la película La flor de mi secreto (1995). 


\section{RASTKO BULJANČEVIĆ}

sonoro, especialmente la marcha progresiva de tresillos, representa la preservación musical de una identidad inestable y caótica, desarrollada y profundizada dentro del proceso dramatúrgico-narrativo.

El órgano para la protagonista representa su deseo de conservar una parte de su hijo, que en cierto modo permitirá que Esteban siga viviendo. Habiendo atravesado por una tragedia muy reciente, Manuela necesita un consuelo a toda costa, por lo cual decide convertir el corazón de su hijo en algo "indestructible". Con este acto, ella no salva a su hijo, sino su memoria y su propio estado mental de la destrucción total, es decir, que su ego prolonga su dolor inconscientemente activando el mecanismo de defensa. Además, Manuela siente la necesidad de descubrir la identidad de la persona a quien dona el corazón de su hijo, deseando por lo menos tener la oportunidad de observar su cara desde la distancia. Katarina Petrović indica que la persona frecuentemente es consciente de la realidad de una manera indirecta, a través de seres y objetos a los cuales está fuertemente vinculada (Petrović, 2016, p. 37). En consecuencia, exclusivamente después de la pérdida, el dolor mental nos mueve a una acción clara, y finalmente hay un motivo para buscar ayuda (Petrović, 2016, p. 37). A través de la identificación con el objeto perdido, Manuela está tratando de sustituir y recompensar la pérdida y artificialmente llenar el vacío interno. La representación musical de un dolor emocional está intensificada con el sonido del clarinete, mientras las oscilaciones rítmicas (en la parte de piano y las cuerdas) representan un retrato sonoro de una reconciliación incompleta con su detrimento y abatimiento impetuoso. La situación de la protagonista adquiere la fuerza trágica de un destino, que a primera vista parece irrecuperable. Por lo tanto, los conflictos melódico-rítmicos, especialmente del tema La mecánica del trasplante, parecen mostrar los rastros de sus identidades perjudicadas, sin la capacidad de redondear completamente el flujo musical, que en este caso simboliza la personalidad herida de Manuela.

Durante el desarrollo de la acción de la película, se asiste a la lucha de la protagonista por la restauración y búsqueda de su propia identidad que había reprimido violentamente hace 17 años. El único motivo que mantiene lúcida a Manuela es la promesa incumplida a su hijo, debido a que finalmente decide reencontrarse con el padre de él, un transexual promiscuo de quien huyó. De repente, la protagonista aparece en la escena en un tren que se desplaza de Madrid a Barcelona. Emocionalmente agotada, está reviviendo su recuerdo cuando hace diecisiete años pasó por el mismo camino, pero al revés. En ese momento clave de la película, junto con la constitutiva voz en off de Manuela aparece la canción Tajabone [19:58-22:47], acompañándola en su trayecto ${ }^{27}$.

MANUELA (la voz en off): Hace diecisiete años hice este mismo trayecto, pero al revés: de Barcelona a Madrid. También venía huyendo, pero no estaba sola. Traía a Esteban dentro de mí. Entonces huía de su padre, y ahora voy en su busca (Almodóvar, 1999, p. 38).

\footnotetext{
${ }^{27}$ Se refiere al hecho de que la canción Tajabone, interpretada por el cantante nigeriano-senegalés Ismael Lô, solamente la pueden oír los espectadores filmicos.
} 
Dramáticamente introduciéndola a los oyentes fílmicos, la canción aparece continuamente unida al hilo musical compuesto por Alberto Iglesias. Mientras el tren está pasando por el túnel, acompañado con el sonido incidental de la guitarra, todo parece como arrastrado por algún movimiento que revive los recuerdos reprimidos, pero claramente no olvidados, de la protagonista. Para Ernesto Acevedo-Muñoz, el túnel simula el interior del canal del parto (cfr. Acevedo-Muñoz, 2007 y Seguin, 2009), que metafóricamente está apuntando a la maternidad y, además, coincide con la búsqueda del padre (Acevedo-Muñoz, 2007 o Petrović, 2016). Aunque para la mayoría de secuencias fílmicas del cine almodovariano, la música vocal o vocal-instrumental obtiene un discurso vocal en español, portugués, inglés, alemán o francés, que es capaz de entender una parte de la población, el texto de la canción Tajabone es incomprensible para una gran parte de audiencia mundial, también para el propio Almodóvar según sus palabras. El director manchego enfatiza que esa canción, cuyas palabras no entiende, es muy adecuada para una ciudad como Barcelona, compartiendo el siguiente pensamiento:

\begin{abstract}
Esta canción la conozco desde hace un año y medio y la adoro, me ha impresionado tanto que he pensado: «Tienes que ponerla en la próxima película que hagas". Luego pega o no pega. He empezado a rodar Todo sobre mi madre, he pensado en el momento en que iba a ponerla, también he planeado el momento para que se despliegue como una harmónica inmensa y para que abrace toda la ciudad, Barcelona en este caso. [...] Oí la canción, flipé, me gustó mucho, lloré y decidí ponerla en la película. Pero no sé lo que cuenta. La puse en la película como un traje, cae divinamente con las imágenes. Y sin embargo, no conozco el sentido de la letra (Seguin, 2009, p. 242).
\end{abstract}

Sin embargo, aunque la canción preexistente está artificialmente añadida al desarrollo narrativo de la película sin tener relación textual con el guion, su sonido, a través del motivo de la muerte, interconecta el carácter primordial de la referencia musical con la figura del hijo perdido. Según Mónica Tovar Vicente, la canción denota el fin del año musulmán a través de la alusión a Abdou Diambar ${ }^{28}$, un ángel encargado de recibir a los fallecidos en el cielo (2016, p. 342), lo que en la película podría interpretarse como un referente conceptual (abstracto) a la muerte del joven Esteban. Además, existe una interconexión comunicativa y heterotópica entre dos culturas diferentes: la imagen del templo expiatorio de la Sagrada familia como un símbolo del cristianismo católico versus la recontextualización sonora de la fiesta religiosa del Ramadán para los musulmanes ${ }^{29}$.

\footnotetext{
${ }^{28}$ Ese sería el nombre del ángel según un diccionario wolof-francés y francés-wolof (Diouf, 2003, p. 45).

${ }^{29}$ Una interpretación similar ofreció Debra Ochoa (ver Ochoa, 2014, p. 132-133).
} 


\section{RASTKO BULJANČEVIĆ}

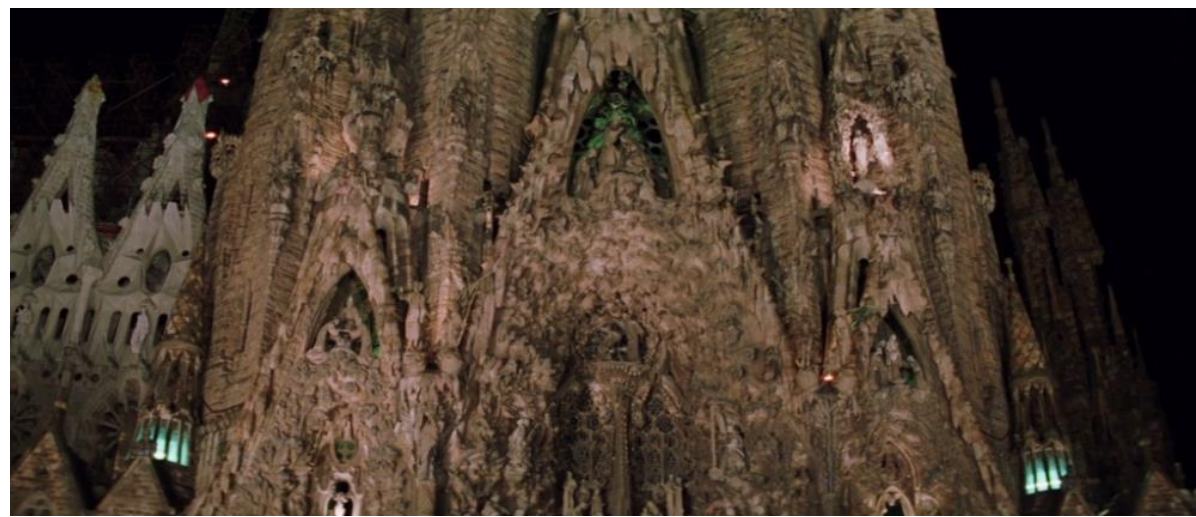

Fig. 2: Interconexión de la canción Tajabone y la imagen de la Sagrada familia.

(C) EL DESEO, D.A., S.L.U.

A pesar de no tener rastros de identidad de la cultura africana, Manuela, como la gran mayoría de los inmigrantes, hasta cierto punto siente nostalgia por su hogar, encontrándose en una búsqueda constante para tener su propio espacio. No obstante, en ese caso la nostalgia no está transmitida a través de un sonido romántico o utópico, sino con el sonido híbrido de la armónica que proviene de un entorno rural, pero al mismo tiempo multiculturalmente relaciona la cultura euroatlántica con los símbolos tradicionales y exóticos de la nación africana $^{30}$. Ese contenido musical geográficamente relocalizado, puede ser identificable para la gran mayoría de las personas, especialmente para las minorías étnicas, culturales (africanos), religiosas (musulmanes) o nacionales (nigerianos y senegaleses). Por lo tanto, aunque la canción no está directamente relacionada con la ideología cristiana o acontecimientos vinculados con la vida de la protagonista, Tajabone refleja adecuadamente el espíritu de Barcelona - la ciudad de "los otros" ${ }^{31}$, de todos aquellos que no pertenecen a sí mismos, a una comunidad o a las reglas de la misma que "nosotros" no entendemos, aunque podemos sentir o empatizar con ellos. En consecuencia, el metatexto de la canción auténtica se inscribió con éxito con su otredad sonora en el tejido audiovisual de la película, reconstruyendo y modificando las identidades ya construidas como la personal, cultural, religiosa y geográfica. Mientras Manuela examinaba y reflexionaba profundamente sus decisiones vitales, observando en silencio los símbolos de la ciudad, mediante la simulación musical se reviven y reconstruyen los fragmentos del pasado que, por malos recuerdos, fueron rechazados por la protagonista. Cuando ella está en silencio, su silencio denota su

\footnotetext{
${ }^{30}$ Aunque no sea un representativo estricto de la cultura africana, el sonido híbrido de la armónica en este caso se entiende como un catalizador de la música africana. Incluso se podría argumentar que la canción Tajabone conceptualmente denota los espacios que originariamente pertenecieron a una cultura africana, relocalizándolos en otro ámbito multicultural - la ciudad Barcelona. El argumento que podría explicar la interconexión de las dos culturas opuestas es el mismo medio cinematográfico, que, operando como una heterotopia (ver, por ejemplo, Foucault, 1967/2008), simultáneamente une diferentes espacios de la alteridad. Esos "contraespacios" heterogéneos y múltiples también son transmisibles al sonido que, según Josh Kun (2005), podríamos llamar audiotopia. En ese caso, audiotopia representa un conocimiento musical conceptual que revela diversas particularidades transmitidas por la unificación del potencial sonoro y visual del medio cinematográfico: lo visual de Barcelona (la imagen de la Sagrada familia) y lo audible de la canción senegalesa que en su tejido incluye la movilidad espacial de la música misma.

31 Mark Allinson (2001) definió Barcelona como una ciudad más exótica, cosmopolita y menos española (p. 198), lo que afirma la pluralidad identitaria y discursiva dentro de su enotrno multicultural.
} 
pérdida, pero también la perdida de todos aquellos a quienes les falta alguien o algo importante en su vida. La ausencia de la voz alta de Manuela simboliza su llanto interno, pero también evoca la solidaridad y la sensación de pertenencia con la alteridad de otros individuos o colectivos. De hecho, por mediación del contenido musical constitutivamente evocador, gran parte de la audiencia está visualizando y compartiendo los momentos trágicos junto con Manuela, identificándolos como parte de su propio mundo. Precisamente la canción Tajabone sería una representación musical de los problemas identitarios (tanto individuales como sociales) muy complejos, que una vez más denotan los elementos de la precariedad humana. La mezcla inhabitual de los sonidos de armónica y guitarra ${ }^{32}$ incrementa aún más la intensidad de la fragilidad. Tratando de escapar de la realidad traumática, Manuela destruyó todos los vínculos con su vida anterior. Ahora, después de tantos años, se ve obligada a enfrentar experiencias dolorosas del su pasado traumático. La muerte de su hijo es como un quiebro en la existencia de Manuela, una fisura que se transmite hacía los espectadores como fragmentos arruinados, dispersos y suprimidos de su identidad, mientras el contenido musical sostiene una construcción sonora polivalente adaptada a la dramaturgia audiovisual de la escena. Es interesante mencionar que el final de esa secuencia fílmica termina con un choque sensorial y perceptivo, formando parte de una expresión audiovisual discontinua que dramática, emocional y narrativamente separa y conecta simultáneamente dos escenas diferentes. Inesperadamente, con la aparición del personaje de Agrado, una amiga transexual promiscua del pasado de Manuela, aparecen elementos de humor trágico-cómico, incluso bizarro, que forman parte muy importante de la sensibilidad y expresión poética de Almodóvar.

Después de su llegada a Barcelona, la protagonista recupera las amistades de su pasado. Conoce a la actriz Huma Rojo y a Hermana Rosa - la mujer joven y una de las víctimas de Lola ${ }^{33}$. Ahora está logrando construir nuevas relaciones cercanas, con las mujeres que atraviesan varios conflictos tanto internos como externos y crisis de identidad. Agrado se prostituye por dinero y por eso arriesga su seguridad, Rosa está embarazada y seropositiva, mientras que Huma está en una relación destructiva con la joven actriz Nina Cruz (Candela Peña $)^{34}$. En la escena en la que Rosa imprevistamente encuentra una foto de Esteban, Manuela responde brevemente que su hijo murió en un accidente, advirtiéndole que no toque

\footnotetext{
32 Según Kathleen Vernon (2009), la combinación sonora de la armónica y la guitarra, junto con el idioma senegalés, forma una hibridación que resuena con los cuerpos transexuales de Lola y Agrado (p. 55). No obstante, el proceso significativo del sonido de armónica y guitarra se podría explicar a través de la retórica musical, es decir, por mediación de los tópicos y gestos musicales que obtienen una validez semántica. Las operaciones estructurales clarifican una de las connotaciones denotativas de la banda sonora, reexaminando las convenciones estilísticas del mbalax - el género musical al cual pertenece la canción Tajabone. Observando las figuras musicales específicas, como el riff introductorio de la guitarra, la sincopación representaría un referente compositivo rítmico-musical que posee un significado tanto referencial como connotativo, un símbolo muy reconocible para la cultura musical africana, posible de detectar sensorialmente. Por otro lado, la esencia del sonido de la armónica, especialmente de las notas repetitivas, está potencialmente vinculado con el self herido y huidizo de Manuela y todos los individuos y colectivos que se identifican a través de ello.

${ }^{33}$ Lola es la persona que contagió a Rosa con el virus.

34 Por eso su relación se parece más a una relación entre una madre e hija (cfr. Strauss, 2001, p. 159), pero una "hija" agresiva y posesiva que tiene afición a los vicios. No obstante, a diferencia de la opinión freudiana, la agresión según Kohut no implica la expresión de una necesidad primaria de destruir, sino, más bien, el impulso agresivo siempre surge en circunstancias psicológicas muy específicas (Kohut, 1996b, p. 198).
} 


\section{RASTKO BULJANČEVIĆ}

su cuaderno. El diario de Esteban es lo más sincero, lo más íntimo que le "dejó" su hijo, representando un objeto materializado que todavía quiere reservar para sí misma, aún no preparada para compartirlo con nadie. Justo en ese momento de la película, se escucha el tema No me gusta que escribas sobre mí [36:27-38:13], musical y contextualmente atado por la partitura Esteban mi hijo [05:21-05:45]. El bloque musical No me gusta que escribas sobre mí se caracteriza por la presencia de un ostinato rítmico-melódico que está unificando (la dramaturgia de) las imágenes, el sonido y los momentos de transición entre las acciones (Iglesias Prieto, 2015, p. 340), es decir, la música está conectando tres imágenes visuales que revelan un núcleo instintivo del sí mismo de Manuela. El sonido extradiegético del tema musical directamente reconstruye su memoria, o, mejor dicho, los momentos que ha pasado con su hijo. La melodía principal se compone de los sonidos de los instrumentos de cuerda y el piano, que en este caso proyectan la regresión asociativa de la protagonista con el trauma del pasado que, todavía, no está resuelto. Manuela vio el póster del último espectáculo Un tranvía llamado deseo, que contempló con Esteban, reviviendo otra vez la imagen de su cara. El contenido musical describe y adicionalmente intensifica la escena de amargos recuerdos de la protagonista, los que todavía no puede dejar atrás. El sonido de la trompeta está incrustado en el desarrollo narrativo del hilo musical, que en este caso está separando el estado mental actual de Manuela y la memoria asociativa de su hijo muerto. Por consiguiente, el sonido mencionado puede representar una señal de la diferenciación simbólica entre el pasado y el presente o, paradójicamente, un hilo cohesivo que los une. La protagonista decide ir a ver la misma actuación, cuando a través de una manifestación musical vemos los rastros de sus identidades todavía fragmentadas con la incapacidad de afrontar la pérdida, pero esta vez sin la supresión de los sentimientos que causa una realidad dolorosa. A un nivel simbólico, solamente simbólico, bajo el flujo de esa banda sonora se puede reconocer la representación musical de su self defectuoso y traumatizado, que todavía no puede interactuar con "los otros" de un modo constructivo.

Al mismo tiempo, mientras se está enfrentando a sus recuerdos dolorosos, Manuela se ató a otras personas (femeninas) con sinceridad y amor (Petrović, 2016, p. 38), lo que apunta a su capacidad para tolerar la ambivalencia (Petrović, 2016, p. 38). En consecuencia, se puede notar el escape de Manuela a una vida grupal (Petrović, 2016, p. 38), que lleva a los personajes que libremente comparten sus temores internos. De hecho, las relaciones sociales de los individuos heridos forman una parte crucial de la dramaturgia y poética fílmica, debido a que el componente sonoro libera y revitaliza las emociones de melancolía, nostalgia y profunda emotividad imbuida de humor, calidez y empatía. Eso confirma que la identidad social y la identidad personal, a pesar de ser conceptualmente distintas, en realidad están inextricablemente vinculadas (Hargreaves, Miell y MacDonald, 2002, p. 9). La amistad inusual e inesperada, pero paradójicamente sincera y transparente, entre Manuela y Huma sería una de las relaciones insinuadas. Una de sus conversaciones y recuerdos comunes está acompañando el tema Todo sobre mi madre [39:34-41:55 $]^{35}$, que permanece en la ambigüedad entre la armonía tonal y modal (cfr. Iglesias Prieto, 2015, p. 104), lo que, curiosamente, concuerda con la ambigüedad de Manuela o incluso con su ambivalencia identitaria. Los fragmentos musicales de las cuerdas, piano, celesta, percusiones y clarinete se integran con

\footnotetext{
35 Con este tema musical, Almodóvar e Iglesias cierran la película.
} 


\section{CONSTRUCCIÓN Y APROXIMACIÓN MUSICAL A LAS IDENTIDADES FRÁGILES EN LA} PELÍCULA DRAMÁTICA TODO SOBRE MI MADRE

frecuencia en la narrativa fílmica ${ }^{36}$, manifestándose en la forma de un leitmotiv de una entidad melódica fluida, pero con un sonido concreto, es decir, un motivo de la nostalgia, reexaminación, perdida, incertidumbre y una represión interna, que no se desarrolla o independiza completamente durante la proyección fílmica completa. Una de las razones potenciales para la interpretación de lo dicho sería que simplemente ese tipo de tratamiento es una parte original de la poética musical neorromántica e individualista de Alberto Iglesias ${ }^{37}$. No obstante, en toda su consistencia musical y dramática, la separación e integración continua del motivo de la trompeta en el tejido audiovisual, además de representar el sonido especificador de Esteban, se refieren particularmente a una metafórica sublimación de un "self errante" de Manuela, un self incapaz de integrarse completamente. Ese tipo del sí mismo lo encontramos con frecuencia en la fragilidad humana, por lo cual el sonido de la trompeta simbólicamente apunta a una identidad no coherente, representando una apertura audible que transmite su fragmentación e individualización remanente. El parte del piano está ocasionalmente apoyado por los trémolos de violoncelo y sonidos fragmentados de la marimba $^{38}$ y el drum kit. A través del sonido de piano, que durante el desarrollo musical cambia la textura, se revelan las oscilaciones identitarias que caracterizan el sí mismo desintegrado de Manuela, pero esta vez la trama no está enfocada solamente en ella, sino al entorno de la escena que sugiere otro tipo de búsqueda: la búsqueda de Nina Cruz. Con ello conviene concluir que el tema musical Todo sobre mi madre no pertenece solamente a Manuela, sino a toda la comunidad femenina o el medio ambiente que todavía no alcanza la etapa de sublimación.

La protagonista está en una búsqueda continua para encontrar su propio espacio, al mismo tiempo que hace partícipe de un papel de amiga devota a Rosa, es decir, hacia su chantaje emocional oculto. Es más, el "vacío de madre" Rosa lo intenta colmar en Manuela (Poyato Sánchez, 1991, p. 28), así mostrando su propia fragilidad y dependencia de los "otros" individuos, es decir, su insuficiencia. Pero Rosa no lo está haciendo para establecer una imagen grandiosa de sí misma, sino, más bien, por la necesidad de construir una relación empática (a través del objeto del self idealizado de Manuela) que no podía establecer en su infancia. Mientras Rosa y Manuela se están abrazando, se escucha el tema Igualita que Eva Harrington [50:11-51:45] $]^{39}$, con el contenido musical que parcialmente ya ha sido incorporado en los temas La mecánica del trasplante y All about Eve [3:17-3:55], pero con una expresión y versión sonora modificada, incluyendo el material tímbrico. El componente musical, otra vez, está interactuando con el ambiental, particularmente con la escena de actuación durante la obra teatral. De esa forma, Almodóvar está profundizando aún más en la perplejidad de

\footnotetext{
${ }^{36}$ Comparado con el resto de la banda sonora, este tema musical se caracteriza por la diversidad y variedad en la orquestación.

${ }^{37}$ Comentando el lenguaje musical de Alberto Iglesias, historiador del arte Carlos Roldán Larreta (2002) notó que el estilo del compositor español marca una "fusión plena" en vez de la independencia entre la imagen y música (párr. 3), lo que anula la autonomía de su banda sonora y por lo tanto disminuye su valor estético.

38 Por otro lado, en el sonido de marimba Rebeca Iglesias Prieto (2015) reconoce "cierta entidad melódica" (p. 104). Sin embargo, no podemos hablar de una entidad melódica coherente, sino de la incircuncisa y fragmentada.

${ }^{39} \mathrm{El}$ nombre del tema musical representa otra referencia intertextual a la película Eva al desnudo (All about Eve, Joseph L. Mankiewicz, 1950), cuando Nina compara a Manuela con el personaje de Eva. Se trata de la misma obra cinematográfica que los personajes de Manuela y Esteban ven al inicio del filme.
} 


\section{RASTKO BULJANČEVIĆ}

Manuela y la intensidad de la narración fílmica en general. Aunque la continuidad progresiva del ostinato rítmico-melódico está interrumpida, la dramaturgia audiovisual todavía queda sin resolver, como el "self errante" de Manuela (anteriormente anunciado por mediación del sonido de armónica en la canción Tajabone) con una representación fluida.

Explicando a Huma la importancia de su papel de Stella en la obra teatral Un tranvía llamado deseo, que no deja de acompañar a Manuela en su trayectoria vital, y cómo la misma obra marcó su vida por completo, Manuela finalmente confía parte de su historia.

MANUELA: Un tranvía llamado deseo ha marcado mi vida. Hace veinte años interpreté el papel de Stella con un grupo de aficionados. Allí conocí a mi marido, él hacía de Kowalski. Hace dos meses vi vuestra versión en Madrid. Fui con mi hijo. Era la noche de su cumpleaños. A pesar de que llovía a mares os esperamos en la calle, porque él quería un autógrafo tuyo, Huma. Era una locura esperar bajo la lluvia, pero como era su cumpleaños, no me atreví a decirle que no. Vosotras cogisteis un taxi y él corrió detrás. Un coche que venía por Alcalá lo atropelló y lo mató. Esa es la explicación Huma, esa es la explicación (Almodóvar, 1999, p. 85).

De acuerdo con la opinión de Katarina Petrović, hasta ese momento Manuela estaba sola: como construcciones metafóricas únicamente existían tres trayectorias importantes de su vida: un túnel, una obra de teatro y el diario de su hijo, como el único testimonio de su pasado (2016, p. 41). Esa revelación, como una parte crucial en el desarrollo narrativo de la acción es intensificada con el tema Otra vez buyendo y sin despedirme [59:19-1:00:16], acompañando la finalización de una parte crucial del progreso y reintegración del sí mismo. Observando la línea melódica del piano, que está sincompada con grandes saltos interválicos, es posible notar la función interiorizada de la música. El tema sonoro establece y traslada una relación de la protagonista hacia su pasado reprimido, mientras las secciones fragmentadas de las cuerdas representan una simulación musical de la huida traumática de Manuela. Quizá eso podría explicar por qué incluso la sonrisa de Manuela parece triste, cuando hasta la música, según Guilherme Maia, denota esa tristeza (Maia, 2010, p. 22). La dicotomia entre las cuerdas e instrumentos de viento metafóricamente podría representar el encadenamiento de sus fragmentos arruinados, es decir, el intento de reconstrucción y reparación de su propio self desintegrado. Acompañando la división entre imágenes en la escena, la transmisión sonora está contando su historia inherente. Los sonidos del vibráfono y marimba, casi en ecos, están apoyando una discontinuidad del espacio de la protagonista, su interacción con el ambiente, junto con la asimilación y aceptación de sí misma, lo que está escondido entre los cambios de secuencias fílmicas.

La adhesión sonora en la secuencia musical introductoria de la película vuelve a aparecer con el tema ¿Qué edad tiene usted? [1:19:34-1:20:57], pero esta vez musicalmente revitalizando y mostrando los recuerdos de la Hermana Rosa durante su trayecto hacia el hospital. Algunos recursos melódicos de esa partitura están extraídos del tema introductorio Soy Manuela, pero con una connotación distinta, dirigida más hacia el personaje de Rosa. Se podría decir que los (extradiegéticamente emitidos) sonidos musicales están constituyendo la 


\section{CONSTRUCCIÓN Y APROXIMACIÓN MUSICAL A LAS IDENTIDADES FRÁGILES EN LA} PELÍCULA DRAMÁTICA TODO SOBRE MI MADRE

fragilidad de los personajes, uniendo sus propias historias impactantes. El desahogo del sentimiento nostálgico de Rosa se interpone entre su realidad dolorosa y la infancia durante su último reencuentro con su perro y padre amnésico que no la reconoce.

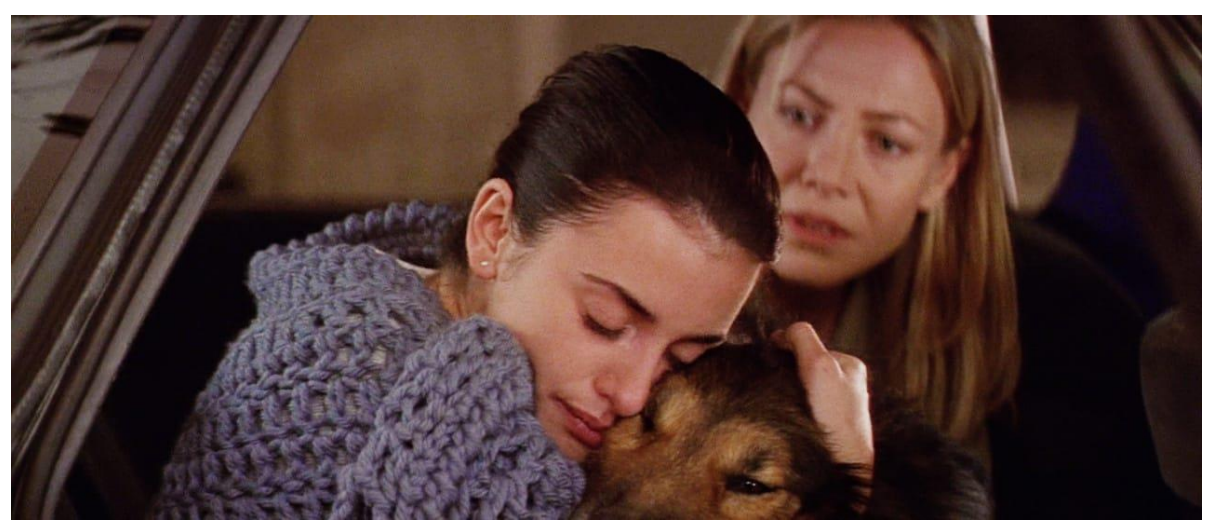

Fig. 3: La emisión sonora empática: el último reencuentro de Rosa con su perro.

(C) EL DESEO, D.A., S.L.U.

Para intensificar aún más el efecto emocional de la música, el fraseo interfiere con la poética de la imagen cinematográfica, prologando el último encuentro y así permitiendo a Rosa que vuelva, por última vez, a sí misma. La impresión de la tragedia, que había anticipado la propia Rosa, está aún más fortalecida por el sonido del piano, pero esta vez, la aproximación sonora está "proponiendo" una conclusión: sin rendirse, Rosa aceptó su destino y su retorno a sí misma, sintiéndose preparada para lo que viene. Por lo tanto, la música en esta secuencia fílmica tiene una función constitutivamente evocadora, profundizando el significado de la imagen mental de Rosa. Su muerte se anuncia a través del sonido conmovedor y angustioso del acordeón mientras los espectadores todavía no conocen cómo va a desarrollarse la historia. A pesar de lo poco que duró esa incertidumbre (no más de un par de segundos), el componente musical es el que predece inesperadamente el final de Rosa.

Durante el entierro de Rosa, el tema preexistente, pero al mismo tiempo emocionalmente y dramáticamente muy bien adaptado en el entorno de la escena, Coral para mi pequeño y lejano pueblo [1:22:47-1:26:04], está acompañando el reencuentro tan esperado de Lola y Manuela ${ }^{40}$. Finalmente, después de casi 18 años, Manuela se acercó gradualmente al padre de su hijo, informándole de que vino a Barcelona solamente para decirle el hijo murió en un accidente.

\footnotetext{
${ }^{40}$ El fragmento de esa banda sonora, compuesta por Dino Saluzzi, tiene una duración más larga en la película. Además, la duración original de la canción supera los 8 minutos.
} 


\section{RASTKO BULJANČEVIĆ}

LOLA: Siempre soñé tener un hijo. Tú lo sabes.

MANUELA: Sí, lo sé. Cuando me fui de Barcelona iba embarazada de ti.

LOLA: ¿Qué?

MANUELA: Sí.

LOLA: ¿Y lo tuviste?

MANUELA: Sí. Un niño precioso.

LOLA: ¡Quiero verle! ¿Los has traído contigo?

MANUELA: No. Está en Madrid, pero no puedes verle.

LOLA: Aunque sea de lejos, Manuela, te prometo que él ni siquiera me verá. Es lo último que te pido.

MANUELA: No puedes verle.

LOLA: ¡Manuela, por favor!

MANUELA: Hace seis meses... le atropelló un coche... y lo mató. Vine a Barcelona sólo para decírtelo. Lo siento. ¡Lo siento! (Almodóvar, 1999, p. 111).

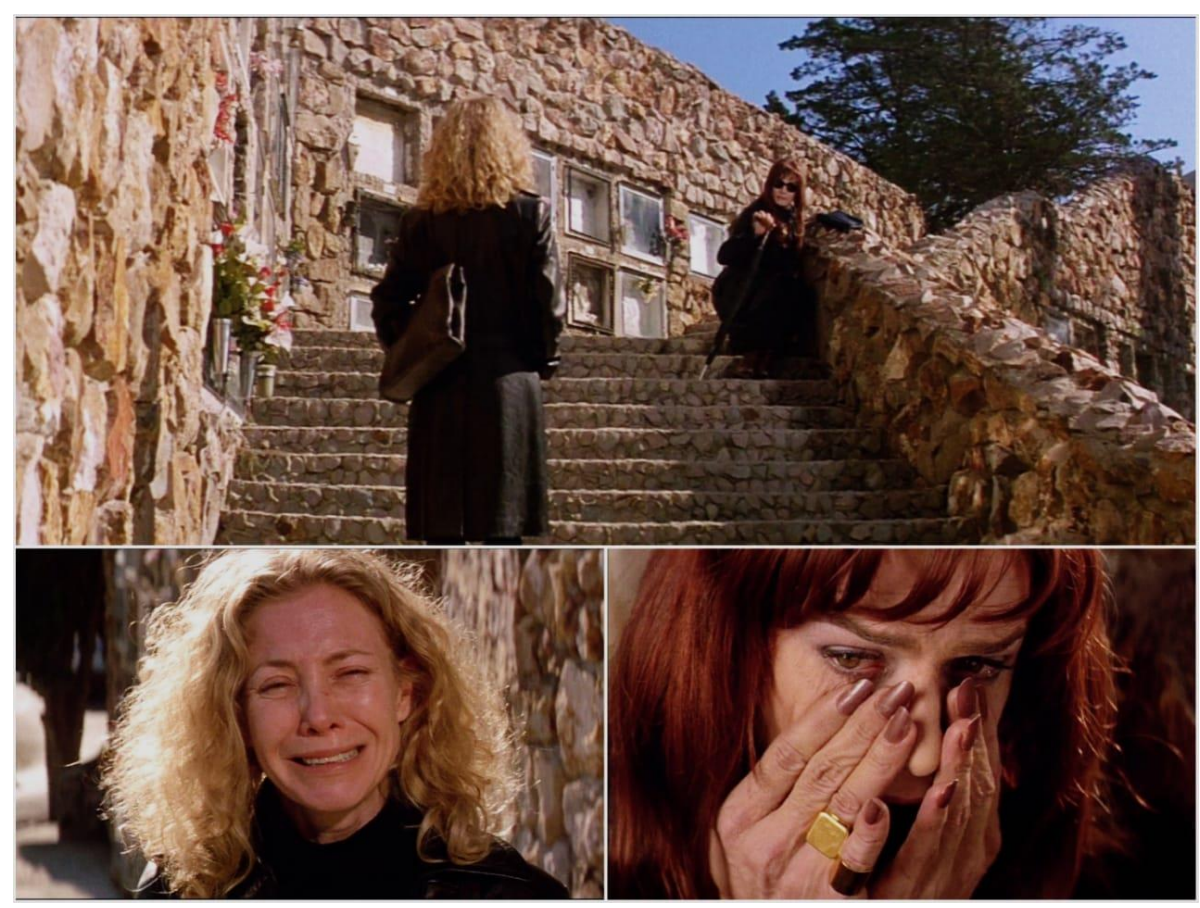

Fig. 4: El reencuentro de Manuela con Lola acompañado por el sonido del tango. (C) EL DESEO, D.A., S.L.U.

La psiquiatra serbia notó que, en esta escena tan impactante, la presencia de la música de tango se comunica fuertemente con los sentimientos de los personajes y el público, ejemplificando la culminación de un entierro emocional que sacude a Manuela en sus esfuerzos por cumplir el deseo de su hijo (Petrović, 2016, p. 42). Como uno de los símbolos de la identidad nacional argentina o patrimonio cultural latinoamericano, la música de tango, 
a través del sonido del acordeón y la guitarra, en esa secuencia fílmica sería una representación musical de las indagaciones añejas, cuya alteridad (incluyendo el espacio geográfico) se inscribió permanentemente en el ser de Manuela. A través del contenido musical, la reconstrucción del pasado de Manuela no está enfocando su nostalgia hacia Argentina ${ }^{41}$, sino que está apuntando a los elementos identitarios que indudablemente producen los sentimientos de la necesidad de pertenencia - pertenencia que consiste en la asimilación y reconocimiento de su propia existencia. Por mediación del poder y propio conocimiento que posee o construye el sonido híbrido del tango, el oyente fílmico puede reflexionar sobre una parte importante de la personalidad de Manuela: su origen e identidad migratoria. Por otro lado, el sonido dominante del acordeón está subsistiendo durante la conservación completa de Manuela y Lola, sin interferir conceptualmente con la imagen cinematográfica y el contenido del dialogo, pero en ningún caso disminuyendo la importancia o la referencia de la música, ya que la música, en este caso, representa la única alusión directa al pasado de Manuela que a nivel asociativo, cognitivo y emocional simboliza la tragedia de Esteban y la re-asimilación de la misma. El sonido de acordeón, que simbólicamente representa un sonido aniquilador, anuncia la muerte esperada de Lola que parece ahora aceptar su destino, por primera vez en su vida enfocándose en los demás (en su hijo muerto el cual no pudo conocer). De acuerdo con Katarina Petrović (2016), Manuela ahora, por primera vez, está preparada para perdonar (a Lola), lo que apunta al logro de una etapa madura de la integración de su self (pp. 42-43). Justamente el sonido ecléctico y empático del tango está relacionando el tejido visual con el contenido auditivo de la escena, permitiendo a los espectadores que junto a Manuela reciban una catarsis emocional a través del perdón.

Mientras la protagonista está mostrando la foto de Esteban a Lola, junto con los fragmentos del diario de Esteban, reaparece de nuevo el sonido de la trompeta como un motivo/tópico fatídico que está circulando por toda la película ${ }^{42}$. En este caso, dichas sonoridades melódicamente secas se comunican con la imagen de la foto de su hijo, transmitiendo un mensaje sublimado de un self dividido. Es decir, el contenido sonoro narra de la desintegración y de la fluidez de una personalidad adolescente que ya no está físicamente presente en el universo fílmico, pero que sigue viviendo en la memoria permanente de Manuela y probablemente de Huma, quien se queda con su foto.

Aunque la banda sonora se centra principalmente en la trayectoria identitaria de Manuela, no pasó por alto a los otros personajes de la película. Como ya se indicó, el ser de Rosa posee su propio tema musical, el personaje de Agrado se podría identificar a través de una pavana a pesar de su exclusión del montaje, mientras que las características "predictivas" de la música se utilizan en forma de analogías y abstracciones metafóricas para predecir las muertes de Esteban, la Hermana Rosa y Lola. Sin embargo, hacia el final de la película, nos encontramos con un breve fragmento instrumental Ensayo en un teatro desocupado [1:31:37-

\footnotetext{
41 Es interesante la observación de Juan Carlos Ibáñez, quien relaciona el contexto político-histórico de Argentina con la identidad nacional de Manuela y la misma Cecilia Ruth (ver Ibáñez, 2013, p. 163-165). Por ello, el origen nacional de Manuela no debería entenderse como una casualidad, sino como una desición estratégica del director. Los rastros del conocimiento musical, inscrito a través de la partitura preexistente del tango, tambíen directamente indica la identidad migratoria de Manuela y su conexión con Argentina.

${ }^{42}$ Se refiere a la tercera aparición del tema musical Tras el corazón de mi hijo [1:29:21-1:31:04].
} 


\section{RASTKO BULJANČEVIĆ}

1:33:00]. Durante el ensayo de Haciendo Lorca, podemos conectar con las crisis de identidad y la fragmentación del sujeto de Huma. Es más, se implementa la coherencia audiovisual por mediación de la profunda imbricación entre el texto (monólogo de Huma), la música y la imagen cinematográfica (la escena de Huma en un teatro casi completamente vacío). Se trata de una referencia intertextual hacia dos dramas teatrales lorquianos, Bodas de sangre y Yerma, que desarrollan historias profundamente conmovedoras e impactantes, pero con un entorno contextualizador distinto que conserva cierta morbilidad y una esencia trágica ${ }^{43}$. Hasta ese momento, el personaje de Huma no tenía un contenido musical que podría representar su self de una manera referencial, aunque todavía lo manifiesta indirectamente, escondiendo su esencia bajo una máscara de la actuación escénica ${ }^{44}$.

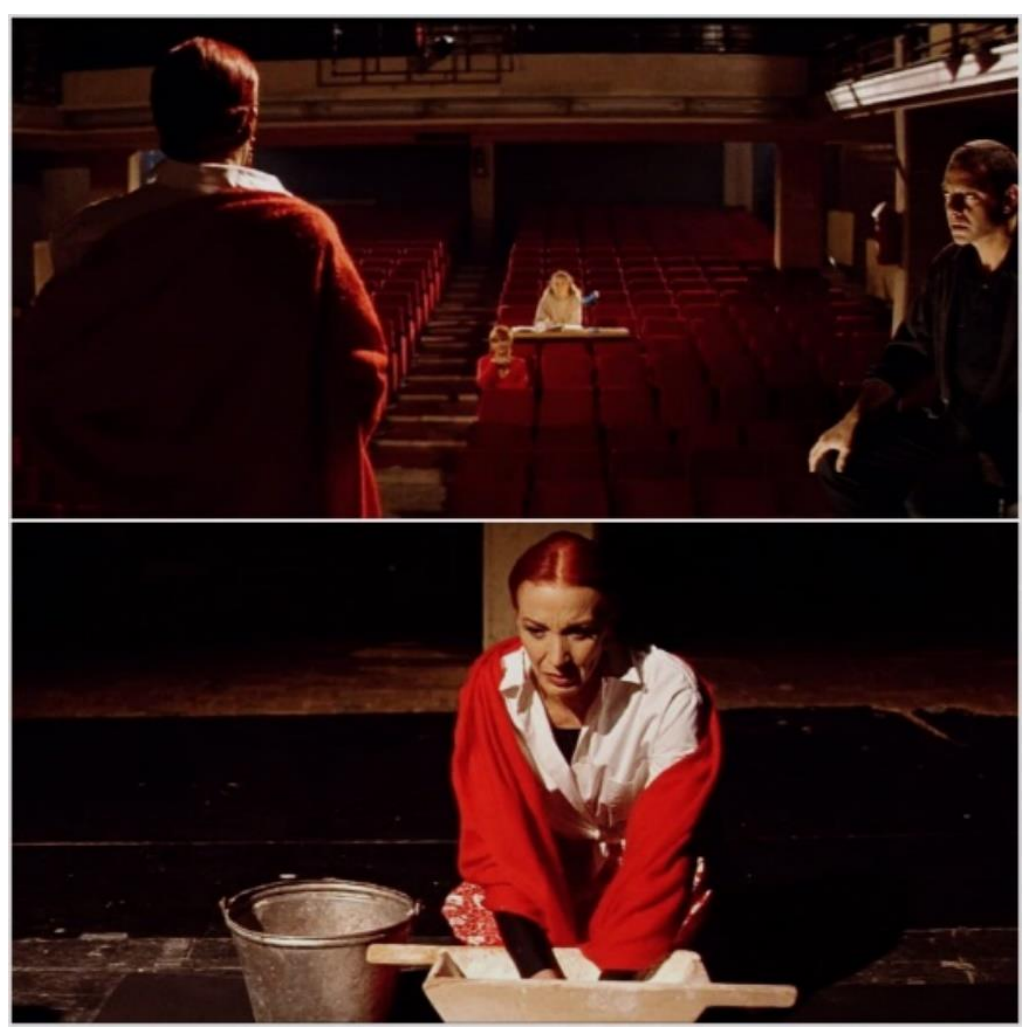

Fig. 5: La disonancia sonora. Huma en el escenario vacío.

(C) EL DESEO, D.A., S.L.U.

$\mathrm{Al}$ infringir las prácticas convencionales del proceso compositivo, se podría decir que esta referencia musical es, en realidad, un significante de discontinuidad que no solamente refuerza la identidad fragmentada de Huma, sino continua a fraccionarlo a través de los motivos sonoros. El bloque musical, que además de la riqueza sensorial muestra una versatilidad creativa de Iglesias, se desvía del resto de la banda sonora, especialmente del recurso melódico que, a pesar de su tempo más lento y su textura transparente suena “espeluznantemente místico". El acorde disonante en la sección de piano representa la

\footnotetext{
${ }^{43}$ Conviene mencionar que el mismo García Lorca murió trágicamente.

${ }^{44}$ En esta obra teatral, Huma interpreta al personaje de una madre que está de luto por la muerte de su hijo.
} 
abstracción musical de un sí mismo desolador de Huma. Es más, el sonido del piano incluso se podría interpretar como el significante sonoro de un vacío interno que no logra colmar a través de las relaciones objetales y, por ello, queda atrapado. La actuación de Huma también está acompañada por las melodías borrosas y repetitivas en la parte de las cuerdas. Precisamente las repeticiones y recurrencias musicales son las que denotan una elevada intensidad emocional de la actriz, cuya imagen mental queda atrapada entre el mundo real y el ficticio. Teniendo en cuenta su relación destructiva con Nina, que por mediación del "traumatismo quijotesco" confunde la realidad y ficción (Maurer Queipo, p. 29), eso simbólicamente podría imputar a una autoidentidad baja que, como la propia estructura musical, no conserva su coherencia. Al contrario del espectáculo Un tranvía llamado deseo, en este ensayo no hay Nina: la frustrada Huma Rojo se quedó sola, abandonada por su amante y privada de su papel como protectora. La disonancia sonora, enriquecida con cromatismos y oscilaciones melódicas en la parte integrante de las cuerdas, además de esconder el conocimiento abstracto de las pulsiones destructivas, posee el conocimiento sobre un estado mental de Huma, que ahora tiene que continuar su vida sin Nina e incluso sin la presencia física de Manuela con la cual estableció una relación empática. Por eso se indica que la actriz metafóricamente sigue viviendo en el mundo de la ficción teatral y que su self, a diferencia del de Manuela, todavía está desintegrado e incompleto.

Manuela deja Barcelona sin despedirse de las chicas del grupo, lo que indica que otra vez está huyendo, pero ahora con un bebé en brazos que acepta como su propio hijo ${ }^{45}$. El tema musical Otra vez buyendo y sin despedirme acompaña la imagen de Manuela en la misma trayectoria, con el mismo túnel y el paisaje ya conocido, pero con una connotación distinta. Diferentes tipos de turbulencias internas y representaciones de las mismas fueron disueltos, indicando un futuro más claro, optimista y prometedor. No obstante, los mismos sonidos, armonías y líneas melódicas, tienen una connotación e intencionalidad de suspense, enfatizando la reapareción de la foto de Esteban. En consecuencia, ¿está surgiendo la pregunta de si el sonido en este caso sigue siendo una asociación directa con las imágenes del pasado imborrable, o simplemente está incorporado en la escena fílmica para redondear el discurso narrativo del tejido audiovisual? Los sonidos del piano, marimba y vibráfono en la última secuencia fílmica se integran en la escena que de repente interrumpe el sonido de las cuerdas, una melodía reaparecida con la misma instrumentación y dramaturgia sonora. Con la excepción de la dedicatoria escrita y los títulos de crédito, las últimas palabras de Huma dirigidas a Manuela -“Te veo luego"- estructuralmente completan la poética audiovisual de la película. La voz y apariencia de Huma poseen una resonancia que anuncia una conclusión densa e inestable, con la recapitulación musical desbordada por la incertidumbre. Es aquí, en el momento en que la música incidental se intercala con la función dramática, cuando su poética sonora va más allá de la supuestamente "inaudible" música cinematográfica. El ritmo de las cuerdas parece una referencia intertextual del tema principal del segundo movimiento del Trío para piano op. 100 de Franz Schubert, cuyo ostinato sonoro (hipotéticamente contextualizándolo dentro de la narrativa audiovisual espacio-temporal) simbólicamente y figurativamente podríamos interpretar como otra proyección de un "self

\footnotetext{
${ }^{45}$ El bebé, que también lleva nombre Esteban, logra de neutralizar el virus.
} 


\section{RASTKO BULJANČEVIĆ}

herido" pero no débil: un self que no huye sino que con éxito asimila nuevos retos, aceptando su fragilidad e imperfección como partes integrantes de "sí mismo". Así el self herido de Manuela, a pesar de la supuesta incertidumbre anunciada a través del sonido empático, logra emerger de la tragedia como un "ganador".

\section{CONCLUSIONES}

Las reivindicaciones de identidades y estrategias comunicativas en la película dramática Todo sobre mi madre, más de 20 años después del estreno, siguen estando abiertas a nuevas interpretaciones. Se ha observado la capacidad connotativa y denotativa de la música, o mejor dicho, del contenido musical, predominantemente extradiegético y original, que para los oyentes fílmicos está invocando diferentes tipos de identificaciones a través de sus funcionamientos sensoriales, cognitivos y emocionales. La interdependencia de los temas musicales, es decir, su estructura compuesta, no solamente indica su interconexión en un nivel dramatúrgico o narrativo, sino, más bien, representa un recurso significativo sonoro para la representación auditiva de las identidades entrelazadas. Los recursos melódicos, junto con las imágenes visuales, reconstruyen y reflexionan sobre diferentes tipos de identidades, cuestionando sus perplejidades, fragilidades, conflictos y pérdidas en el intento de establecer su propia coherencia.

La labor de la música, principalmente (pero no solamente) instrumental, tanto cinematográfica como popular, como una fuente identitaria ha tenido un papel importante en las estrategias del control emocional de los personajes, especialmente para la personalidad de Manuela: la transformación de su conciencia y sus recuerdos individuales y colectivos. La música también describe y profundiza el significado y valor de las memorias agradables de Rosa, demostrando algunos recuerdos melancólicos y afectivamente estimulantes que los espectadores no pueden ver por completo, pero los pueden escuchar. Justamente a través de una escucha activa al componente referencial del lenguaje, la voz de Rosa, o el mismo contenido musical, nos permiten visualizar un fragmento de su pasado que en cierta forma denota una sublimación de su identidad. La ansiedad y turbulencias internas de Huma, que comparado con las de Manuela no se enfatizan lo suficiente en la capa visual de la película, también se expresan gracias al componente musical, especialmente combinado con la representación teatral impactante que, en algún modo, le permite vivir una experiencia catártica. Incluso la imagen de Esteban, aunque post mortem, se revive en gran medida gracias al recurso melódico, especialmente a través del sonido de trompeta, cuando la banda sonora instrumental conceptualmente simboliza un fragmento crucial de su esencia, salvándolo de la aniquilación completa. Por tanto, se podría decir que la música siempre va acorde con el estado psicológico de los personajes o la dramaturgia de la escena y que, al igual que el acercamiento de Kohut a sus pacientes, es empática.

Debido a que la mayoría de las referencias musicales no forman parte de la diégesis durante la proyección fílmica, una de sus funciones se podría relacionar con el concepto estético de la mímesis. Sin embargo, la música de la película Todo sobre mi madre no imita literalmente la (hiper)realidad cinemática o los fragmentos identitarios múltiples de los 


\section{CONSTRUCCIÓN Y APROXIMACIÓN MUSICAL A LAS IDENTIDADES FRÁGILES EN LA} PELÍCULA DRAMÁTICA TODO SOBRE MI MADRE

personajes, sino, más bien, los describe, modifica y reconstruye a diferentes niveles de la sensorialidad, estética, dramaturgia y narración. De hecho, el mismo significado denotativo de la música indica que es posible relacionar directamente el concepto de la fragilidad con el contenido sonoro musical, a través de diversos conceptos de la semiótica estructural, intertextual o existencial (como, por ejemplo, los tópicos, gestos u otros códigos musicales que, en esta ocasión, no han sido profundamente observados) o, por otro lado, mediante los mecanismos del poder de la música (geográfico, religioso, histórico, identitario o cultural), con la cual revela o intencionalmente oculta a la audiencia varios conocimientos, ideologías y verdades, inscritos en el tejido audiovisual polivalente. Por lo tanto, se concluye que la banda sonora musical sí es capaz de mostrar, describir y modificar la reconstrucción y reflexión de identidades, específicamente la incorporación de un sí mismo, con todas sus interpretaciones abiertas, parcialmente subjetivas y despejadas, pero al mismo tiempo revalidadas con las posiciones teóricas más apropiadas en el campo de la musicología fílmica heterógama.

\section{BIBLIOGRAFÍA}

Acevedo-Muñoz, E. R. (2007). Pedro Almodóvar. London: British Film Institute.

Adorno, T. W. \& Eisler, H. (1976). El cine y la música. Madrid: Editorial Fundamentos.

Allinson, M. (2001). A Spanish Labyrinth: The Films of Pedro Almodovar. New York: I. B. Tauris.

Almodóvar, P. (1999). Todo sobre mi madre: edición definitiva del guión de la película con algunas reflexiones, fotografias y textos del autor. Madrid: El Deseo Ediciones.

Althusser, L. (2003). Ideología y aparatos ideológicos del Estado. Freudy Lacan. Buenos Aires: Nueva Visión.

Arredondo Pérez, H. (2014). Andalucía y la mujer en la copla. En F. J. García Gallardo \& H. Arredondo Pérez (Eds.). Andalucia en la música. Expresión de comunidad, construcción de identidad (pp. 125-150). Sevilla: Centro de Estudios Andaluces.

Buljančević, R. (2020). Slušajući film. Muzičkea poetika Pedra Almodovara. [Escuchando la película. Poética musical de Pedro Almodóvar]. (Tesis de Máster). Novi Sad: Universidad de Novi Sad, Academia de las Artes.

Cenciarelli, C. (2021). The Possibilities of Cinematic Listening. En C. Cenciarelli (Ed.). The Oxford Handbook of Cinematic Listening (pp. 1-26). New York: Oxford University Press.

Chion, M. (1993). La audiovisión: Introducción a un análisis conjunto de la imagen y el sonido. Barcelona: Ediciones Paidós. 


\section{RASTKO BULJANČEVIĆ}

Dibben, N. (2002). Gender identity and music. En R. A. R. MacDonald, D. J. Hargreaves \& D. Miell (Eds.). Musical identities (pp. 117-134). Oxford: Oxford University Press.

Diouf, J. L. (2003). Dictionnaire wolof-français et français-wwolof. París: Karthala.

Foucault, M. (1967/2008). On Other Spaces. En L. De Cauter \& M. Dehaene (Eds.). Heterotopia and the City: Public Space in a Postcivil Society (pp. 13-22). London: Routledge.

Foucault, M. (1978). Historia de la sexualidad 1. La voluntad de saber. México: Siglo XXI.

Foucault, M. (1980). Truth and Judicial Forms. En C. Gordon (Ed.). Power/Knowledge: Selected Interviews and Other Writings 1972-1977 (pp. 1-89). Brighton: Harvester Press.

Gabilondo, J. (2005). Melodrama atlántico y migrancia materna. Apuntes sobre Todo sobre mi madre. En F. A. Zurian \& C. Vazquez Varela (Eds.). Almodóvar: El cine como pasión. Actas del Congreso Internacional Pedro Almodóvar (pp. 287-306). Cuenca: Ediciones de la Universidad Castilla-La Mancha.

García Landa, J. A. (1998). Acción, relato, discurso. Estructura de la ficción narrativa. Salamanca: Universidad de Salamanca.

Gorbman, C. (1987). Unheard Melodies: Narrative Film Music. Bloomington: Indiana University Press.

Grainge, P. (2008). Selling Spectacular Sound: Dolby and the Unheard History of Technical Trademarks. En Jay Beck y Tony Grajeda Lowering (Eds.). Lowering the Boom: Critical Studies in Film Sound (pp. 251-268). Champaign: University of Illinois Press.

Hargreaves, D. J., Miell, D. \& MacDonald, R. A. R. (2002). What are musical identities, and why are they important? En R. A. R. MacDonald, D. J. Hargreaves y D. Miell (Eds.). Musical identities (pp. 1-20). Oxford: Oxford University Press.

Ibáñez, J. C. (2013). Memory, Politics, and the Post-Transition in Almodóvar's Cinema. En M. D’Lugo \& K. M. Vernon (Eds.). A Companion to Pedro Almodóvar (pp. 153-176). Oxford: Blackwell Publishing Ltd.

Iglesias Prieto, R. (2015). Alberto Iglesias. Música en la filmografía de Pedro Almodóvar, Tesis doctoral, Universidad de Santiago de Compostela.

Kalinak, K. (1992). Settling the Score: Music and the Classical Hollywood Film. Madison: University of Wisconsin Press. 
CONSTRUCCIÓN Y APROXIMACIÓN MUSICAL A LAS IDENTIDADES FRÁGILES EN LA PELÍCULA DRAMÁTICA TODO SOBRE MI MADRE

Kassabian, A. (2001). Hearing Film: Tracking Identifications in Contemporary Hollywood Film Music. New York: Routledge.

Kinder, M. (2005). Reinventar la Patria: La trilogía de Almodóvar sobre la muerte cerebral. En F. A. Zurian \& C. Vazquez Varela (Eds.). Almodóvar: El cine como pasión. Actas del Congreso Internacional Pedro Almodóvar (pp. 257-268). Cuenca: Ediciones de la Universidad Castilla-La Mancha.

Kohut, H. (1966). Forms and Transformations of Narcissism. Journal of the American Psychoanalytic Association, 14(2), pp. 243-272. Recuperado de https://pdfs.semanticscholar.org/3f8f/6f1d014c93904df3add339a076d537a577e2. pdf.

Kohut, H. (1971). The Analysis of the Self. New York: International Universities Press.

Kohut, H. (1996a). Thoughts on the Self and Its Restoration, Lecture 25 (June 11, 1976). En P. Tolpin \& M. Tolpin (Eds.). Heinz Kobut: The Chicago Institute Lectures (pp. 381-396). Hillsdale, New Jersey: The Analytic Press.

Kohut, H. (1996b). Varieties of Aggression, Lecture 13 (January 3, 1975). En P. Tolpin \& M. Tolpin (Eds.). Heinz Kohut: The Chicago Institute Lectures (pp. 195-210). Hillsdale, New Jersey: The Analytic Press.

Kun, J. (2005). Audiotopia: Music, Race, and America. Berkeley: University of California Press.

Lacan, J. (1998). El Seminario de Jacques Lacan, libro 4: La relación de objeto 1956-1957. Buenos Aires: Paidós.

Lewis, D. (1986). On The Plurality of Worlds. Oxford: Blackwe 11.

London, K. (1936). Film Music: A Summary of the Characteristic Features of its History, Aesthetics, Techniques and its Possible Developments. London: Faber and Faber.

Maia, G. (2010). Do "lixo" ao luxo: um ensaio sobre a música de pós-produção nos almodramas. Contemporanea - Revista de Comunicação e Cultura, 8, pp. 1-33. Recuperado de https://repositorio.ufba.br/ri/bitstream/ri/3508/1/3576.pdf.

Maurer Queipo, I. (2011). Cruzando fronteras: “Todo sobre mi madre” (1999) de Pedro Almodóvar. Revista de comunicación de la SEECI, 24, pp. 28-53. https://doi.org/10.15198/seeci.2011.24.18-34. 


\section{RASTKO BULJANČEVIĆ}

Metz, C. (2001). El significante imaginario: psicoanálisis y cine. Barcelona: Paidós.

Nieto, J. (1996). Música para la imagen: la influencia secreta. Madrid: SGAE.

Ochoa, D. J. (2014). Music and Migratory Subjects in Almodovar's Todo sobre mi madre, Hable con ella and Volver. Confluencia: Revista hispánica de cultura y literatura, 29(2), pp. 129-141.

Petrović, K. (2016). Perspektiva sąrevanja fragilnog identiteta; Almodovar: Granični fenomeni [La perspectiva de madurez de la identidad frágil; Almodóvar: Fenómenos limítrofes]. (Tesis Doctoral). Belgrado: Facultad de Artes Dramáticas (FDU). Recuperado de https://nardus.mpn.gov.rs/bitstream/id/56365/KATARINA.

Poyato Sánchez, P. (2007). Guía para very analizar "Todo sobre mi madre”. Pedro Almodóvar (1999). Valencia y Barcelona: Nau Llibres y Octaedro.

Roldán Larreta, C. (febrero 2002). Música para el cine; semblanza artística del compositor Alberto Iglesias. Euskonews \& Media [Revista electrónica]. Recuperado de https://www.euskonews.eus/0154zbk/gaia15401es.html.

Saussure, F. (1945). Curso de lingüistica general. Buenos Aires: Losada.

Seguin, J. C. (2009). Pedro Almodóvar, o, La deriva de los cuerpos: ensayo. Murcia: Ediciones Tres Fronteras.

Sergi, G. (2001). The Sonic Playground: Hollywood Cinema and Its Listeners. En M. Stokes \& R. Maltby (Eds.). Hollywood Spectatorship: Changing Perceptions of Cinema Audiences (pp. 121-151). London: British Film Institute.

Smith, J. (1996). Unheard Melodies? A Critique of Psychoanalytic Theories of Film Music.

En D. Bordwell y N. Carroll (Eds.). Post-theory: Reconstructing Film Studies (pp. 230-248). Madison: University of Wisconsin Press.

Strauss, F. (2001). Conversaciones con Pedro Almodóvar. Madrid: Ediciones Akal.

Tatarkiewicz, W. (2001). Historia de seis ideas. Arte, belleza, forma, creatividad, mímesis, experiencia estética. Madrid: Editorial Tecnos.

Thomas, T. (1991). The Film Score: The Art and Craft of Film Music. Burbank: Riverwood Press.

Tovar Vicente, M. (2016). Canciones para una filmografía: el empleo narrativo de las partituras con letra en la obra cinematográfica de Pedro Almodóvar. (Tesis Doctoral). Madrid: Universidad 
CONSTRUCCIÓN Y APROXIMACIÓN MUSICAL A LAS IDENTIDADES FRÁGILES EN LA PELÍCULA DRAMÁTICA TODO SOBRE MI MADRE

Complutense de Madrid, Facultad de Ciencias de la Información. Recuperado de https://eprints.ucm.es/id/eprint/35456/1/T36790.pdf.

Vernon, M. K. (2005). Las canciones de Almodóvar. En F. A. Zurian \& C. Vazquez Varela (Eds.). Almodóvar: El cine como pasión. Actas del Congreso Internacional Pedro Almodóvar (pp. 161-175). Cuenca: Ediciones de la Universidad Castilla-La Mancha.

Vernon, M. K. (2009). Queer Sound: Musical Otherness in Three Films by Pedro Almodóvar. En B. S. Epps \& D. Kakoudaki (Eds.). All about Almodóvar: A Passion for Cinema (pp. 51-70). Minneapolis: University of Minnesota Press.

\section{MATERIAL AUDIOVISUAL}

Almodóvar, P. (Director). (1999). Todo sobre mi madre [Película]. Filmax Home Video.

Iglesias, A. (Compositor). (1999). Todo Sobre Mi Madre - Banda Sonora Original de Alberto Iglesias [CD de audio]. Universal Music Spain.

Fecha de recepción: 21/10/2020

Fecha de aceptación: 22/10/2021 